\title{
Do different irrigation techniques affect the small-scale patterns of plant diversity and soil characteristics in mountain hay meadows?
}

\author{
Ramona Laila Melliger • Eliane Riedener • \\ Hans-Peter Rusterholz • Bruno Baur
}

Received: 7 January 2014 / Accepted: 23 May 2014/Published online: 19 June 2014

(C) Springer Science+Business Media Dordrecht 2014

\begin{abstract}
Traditional management practices are suggested to maintain species-rich grasslands. In the Valais, an arid region of Switzerland, hay meadows are traditionally irrigated using open water channels. However, in the past decades this irrigation technique has been increasingly replaced by sprinkler irrigation, which is assumed to result in a more homogeneous water distribution than open water channels. This study examined whether the change in irrigation technique affected the small-scale distribution of plants and soil characteristics in hay meadows in the Valais. Three plots consisting of 13 subplots of increasing size $(0.1 \times 0.1$ to $6.4 \times 6.4 \mathrm{~m})$ were installed in six traditionally and six sprinkler-irrigated meadows. In all subplots, plant species richness and soil characteristics [moisture, $\mathrm{pH}$, total organic nitrogen, organic matter content (SOM), total and plant available phosphorus] were recorded. The type of irrigation technique did not affect the shape of the
\end{abstract}

Communicated by B. G. Warner.

Electronic supplementary material The online version of this article (doi:10.1007/s11258-014-0360-9) contains supplementary material, which is available to authorized users.

R. L. Melliger · E. Riedener $(\varangle) \cdot$ H.-P. Rusterholz ·

B. Baur

Section of Conservation Biology, Department of

Environmental Sciences, University of Basel, St. Johanns-

Vorstadt 10, 4056 Basel, Switzerland

e-mail: eliane.riedener@unibas.ch plant species-area relationship. In none of the meadows did the species area-curves reach the asymptote within the range of plot sizes examined. Mantel $r$ statistics showed that spatial autocorrelation in the soil characteristics examined was low and their smallscale distributions were not influenced by the irrigation technique except for soil $\mathrm{pH}$ and SOM. Our results indicate a pronounced small-scale heterogeneity in the distribution of plant species and soil characteristics for both types of irrigation technique. This can partly be explained by the fact that sprinklers distribute the water less homogeneously than commonly assumed. As applied in the Valais, sprinkler irrigation does not reduce the spatial heterogeneity and hence biodiversity of hay meadows.

Keywords Semi-natural grassland · Water management $\cdot$ Land use change $\cdot$ Species-area relationship - Spatial autocorrelation · Valais (Switzerland)

\section{Introduction}

Semi-natural grasslands including hay meadows are habitats, which were formed by traditional management practices. These habitats harbour numerous species whose primordial habitats have been vastly destroyed (Baur et al. 1997, 2004), and therefore, they are of high conservation value (Poschlod and 
WallisDeVries 2002; Baur et al. 2006). Since the mid twentieth century, changes in land use including intensification and abandonment resulted both in a decline in the area of semi-natural grasslands (Strijker 2005) and in a decrease in plant species richness, especially in grassland specialists (Poschlod and WallisDeVries 2002; Tasser and Tappeiner 2002; Homburger and Hofer 2012; Riedener et al. 2014).

The maintenance of hay meadows and their typical species composition also depends on irrigation, particularly in arid regions such as the south-facing slopes of the Valais in the Swiss Alps. In this region, a dense net of open water channels was constructed from the eleventh century onwards to transport glacial melt water from mountain streams to meadows at lower elevations (Leibundgut 2004). With this water, the hay meadows are flooded at regular intervals. The farmers put a temporary dam across the water channel causing an overflow with a resulting flooding of the downslope parts of the meadow (Crook and Jones 1999). This traditional irrigation technique is very labour intensive (Meurer and Müller 1987). Therefore, the modernization and rationalization of agricultural practices in the Valais have increasingly led to the replacement of the traditional irrigation technique by sprinkler irrigation systems in the past decades (Meurer and Müller 1987; Crook and Jones 1999).

Various elements of meadow spatial heterogeneity affect plant species richness at different scales (Weiher and Howe 2003; Olofsson et al. 2008; Giladi et al. 2011). At the landscape level, different types of land use lead to a mosaic of different habitats, which may impact plant species richness and dispersal of organisms (Gaujour et al. 2012). At the level of a few square metres, microhabitat conditions including the distribution of soil nutrients and water become more important for the spatial arrangement of co-existing plant species and hence plant species richness (Shmida and Wilson 1985; Zhou et al. 2008; Shi et al. 2010). In hay meadows, different management practices including the type of irrigation technique may influence meadow spatial heterogeneity and thus plant species richness. In the present study, we focused on the potential impact of different irrigation techniques on the small-scale heterogeneity of plant diversity and soil characteristics.

Traditional and sprinkler irrigation are assumed to differ in their kind of small-scale water distribution. Sprinklers may distribute the water homogeneously from above over the meadow, whereas in traditional irrigation different parts of the ground are inundated irregularly, depending on the microrelief of the meadows (Meurer and Müller 1987). This spatially unequal water distribution can increase the small-scale variation in both soil moisture and nutrients and may, therefore, lead to a mosaic of different microhabitats and hence to an increased floristic and faunistic diversity (Rosenzweig 1995; Werner 1995; DiaconBolli et al. 2012).

The shapes of species-area relationships have been used to explore spatial patterns of plant diversity in grasslands (Connor and McCoy 1979; Rosenzweig 1995). Meadows with a homogeneous plant distribution reach the maximum species richness (asymptote of the curve) at a smaller area and show a steeper increase in the cumulative species number than meadows with a heterogeneous plant distribution. The recorded spatial small-scale distribution of plant species and thus the shape of the species-area relationship of a meadow can be influenced by different factors including meadow spatial heterogeneity (Kallimanis et al. 2008; Shen et al. 2009; Kolasa et al. 2012), competitive interactions (Tilman 1982), shape and size of sampling plots (Condit et al. 1996), shape of the habitats (Harte et al. 1999), grain size of the vegetation (He and Legendre 2002; Braschler et al. 2004; Hortal et al. 2006), and the length of time taken to conduct sampling (Preston 1960; White 2004). Meadow spatial heterogeneity is assumed to increase with increasing sampling area and may, therefore, be an important descriptor of the species-area relationship (Rosenzweig 1995; Proença and Pereira 2013).

In the present study, we examined the potential influence of the two irrigation techniques on the smallscale distribution of plant species and soil characteristics of extensively managed hay meadows in the Valais. A previous study conducted in the same region showed that traditionally and sprinkler-irrigated hay meadows did not differ in plant diversity and species composition on the basis of $100 \mathrm{~m}^{2}$ plots (Riedener et al. 2013). However, effects of different irrigation techniques on the small-scale spatial patterns ranging from 0.01 to $40 \mathrm{~m}^{2}$ have not been investigated so far.

As a result of unequal water distribution by traditional irrigation, we expect that traditionally irrigated meadows show a higher variation in the pattern of plant distribution than sprinkler-irrigated meadows. Therefore, the shape of the species-area 
curves should differ between the two types of irrigation. In sprinkler-irrigated meadows, the slope of the species-area curve should be steeper and reach the asymptote at a smaller spatial scale than in traditionally irrigated meadows. Spatial autocorrelation can be used as an indicator for spatial heterogeneity of different soil characteristics. High positive values of autocorrelation indicate a high spatial dependency of soil characteristics. The spatial dependency may change in different comparisons of various soil properties. Furthermore, we assume that soil characteristics show a more heterogeneous spatial distribution in traditionally irrigated meadows than in sprinkler-irrigated meadows. In particular, we addressed the following questions: (1) Do traditionally and sprinkler-irrigated meadows differ in the shape of their plant species-area relationships and in the smallscale spatial pattern of soil characteristics? and (2) Are soil characteristics spatially autocorrelated and if yes, at which spatial scale?

\section{Methods}

Study area and survey design

The study was conducted in two areas located on the south-facing slope of the Rhone valley in the canton Valais (Switzerland), namely in Ausserberg $\left(46^{\circ} 19^{\prime} \mathrm{N}\right.$, $7^{\circ} 51^{\prime} \mathrm{E}$, elevation: 1,191-1,255 $\mathrm{m}$ a.s.1.; hereafter referred to as $\mathrm{AU})$ and Guttet-Erschmatt $\left(46^{\circ} 19^{\prime} \mathrm{N}\right.$, $7^{\circ} 40^{\prime}$ E, elevation: 1,281-1,400 m a.s.1.; GE). The two areas are $15 \mathrm{~km}$ apart. Mean annual air temperature in this region is $9.4{ }^{\circ} \mathrm{C}$ and annual precipitation is $596 \mathrm{~mm}$ (MeteoSwiss 2013).

The vegetation types of the hay meadows investigated belonged to the Trisetetum association (Ellenberg 1986). Information on management was obtained by personal interviews with farmers. On most of these meadows, the traditional irrigation technique was replaced by sprinkler irrigation 8-25 years ago. Nowadays, only $10-30 \%$ of the meadows of this region are still irrigated in the traditional way resulting in a mosaic of traditionally and sprinkler-irrigated meadows (K. Liechti, pers. com.). The majority of sprinklers were installed at permanent positions, but on two meadows there were also mobile sprinklers. Management intensity of the investigated meadows is relatively low (see Table S1 for details). The meadows investigated were mown once or twice a year and grazed for a few days in autumn by sheep or cattle. Fertilizer (manure; mean $\pm \mathrm{SE}, \quad 10.8 \pm 3.2 \mathrm{~m}^{3} \mathrm{ha}^{-1} \mathrm{y}^{-1}$ ) was applied every year or every second year in autumn, except for two meadows in AU, which were not fertilized at all. Irrigation occurred every 2 nd or 3rd week during the vegetation period (from May to the end of September in both irrigation techniques). Irrigation frequency and the amount of water applied per irrigation event did not differ between the two irrigation techniques (amount of water: ANOVA, $F_{1,9}=1.51, p=0.25$ ). Moreover, traditionally and sprinkler-irrigated meadows did not differ in the amount of fertilizer or grazing intensity (ANOVA, both $p>0.32$ ). Neither did meadows in the two study areas differ in the amount of water received or grazing intensity (ANOVA, both $p>0.10$ ). However, the amount of fertilizer was marginally higher in GE than in AU (ANOVA, $F_{1,9}=4.62, p=0.06$ ).

Six pairs of hay meadows were chosen in the two study areas, each pair consisting of a traditionally and a sprinkler-irrigated meadow. Four pairs of meadows were located in AU and two pairs in GE. The distance between pairs of meadows was $1 \mathrm{~km}$ in GE and ranged from $50 \mathrm{~m}$ to $2 \mathrm{~km}$ in $\mathrm{AU}$ (see Table $\mathrm{S} 1$ for distances between meadow pairs).

Traditionally and sprinkler-irrigated meadows did not differ in size, elevation, exposure and inclination (ANOVA, all $p>0.19$ ). Neither did meadows in the two study areas differ in exposure or inclination (ANOVA, both $p>0.29$ ). Average exposure was SSE $\left(157 \pm 10^{\circ}\right)$ and average inclination was $18 \pm 1^{\circ}$. However, mean elevation of the hay meadows was $1,222 \pm 7 \mathrm{~m}$ a.s.l. $( \pm \mathrm{SE})$ in $\mathrm{AU}$ and 1,339 $\pm 26 \mathrm{~m}$ a.s.l. in GE (ANOVA, $F_{1,9}=33.54, p<0.001$ ). Furthermore, meadows were smaller in AU than in GE (AU: 3,049 $\pm 623 \mathrm{~m}^{2}$, GE: $6,198 \pm 1,507 \mathrm{~m}^{2}$; ANOVA, $\left.F_{1,9}=5.44, p=0.045\right)$.

\section{Vegetation surveys}

In each meadow, three starting points (lower left corner of a plot) were randomly chosen to install three plots of increasing size using a nested design (Fig. 1). Each plot was built up an initial area of $0.1 \times 0.1 \mathrm{~m}$ (subplot 1). This area was duplicated twelve times to reach a size of $6.4 \times 6.4 \mathrm{~m}$ (subplot 13$)$. The plots had a minimum distance of $2 \mathrm{~m}$ to water channels and trails and of $3 \mathrm{~m}$ to roads to minimize potential edge effects. The distances among the three starting points 


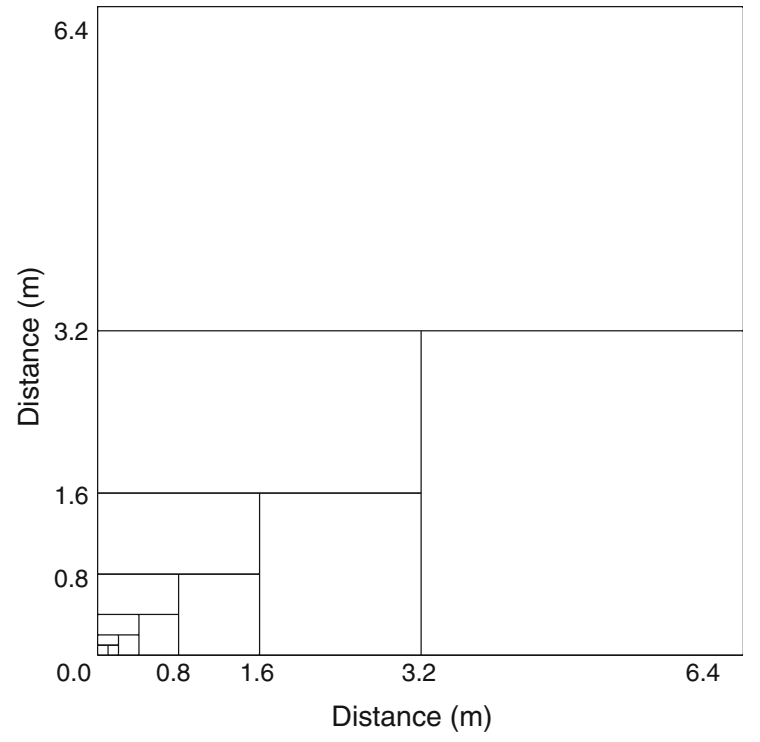

Fig. 1 Nested plot design consisting of 13 subplots of increasing size. The area of the first subplot $(0.1 \times 0.1 \mathrm{~m})$ is doubled 12 times to reach a total area of $6.4 \times 6.4 \mathrm{~m}$

within a meadow ranged from 8 to $40 \mathrm{~m}$. All vascular plant species present in subplot 1 were recorded. In subplot 2 and the succeeding subplots only additional species were recorded. Plant surveys were conducted by R. L. M. and E. R. between May and June 2012. Pseudoturnover, i.e. the turnover accounting for two sampling persons, ranged from 5.3 to $9.8 \%$ (Nilsson and Nilsson 1985).

\section{Soil characteristics}

To analyse the spatial variation in soil characteristics, soil samples were collected in the most central plot of the three plots in each meadow. Beginning in subplot 1, three soil samples were taken close to its centre to a depth of $5 \mathrm{~cm}$ using a soil corer (diameter $5 \mathrm{~cm}$, volume $100 \mathrm{~cm}^{3}$ ) in October 2012. This procedure was repeated in subplot 2 and in the following subplots. The three samples of a subplot were mixed and pooled resulting in 13 soil samples per plot. In this way, 156 soil samples were obtained in the six traditionally irrigated and six sprinkler-irrigated meadows. The soil samples were sieved (mesh size $2 \mathrm{~mm}$ ) and dried for $96 \mathrm{~h}$ at $50{ }^{\circ} \mathrm{C}$. Soil $\mathrm{pH}$ was assessed in distilled water (1:2.5 soil:water) (Allen 1989). Total soil organic matter content (SOM, \%) was determined as loss-on-ignition of oven-dried soil at $750{ }^{\circ} \mathrm{C}$ for $16 \mathrm{~h}$ (Allen 1989) and total soil organic nitrogen content ( $\mathrm{OrgN}, \%)$ was assessed using the standard method of Kjeldahl (Bremner 1965). Finally, total phosphorus content $\left(\mathrm{PT}, \mu \mathrm{g} \mathrm{PO}_{4^{-}} / g\right.$ ) and plant available phosphorus content $\left(\mathrm{PP}, \mu \mathrm{g} \mathrm{PO}_{4^{-}} / g\right.$ ) were extracted using hydrochloric acid (PT) and ammonium acetate (PP) and determined by photometric analyses (Allen 1989).

Soil moisture (\%) was measured on the same spots as soil samples were taken on the same day in October 2013 using a soil moisture sensor (FOM/mts). This resulted in three measurements per subplot. The mean of the three measurements in a subplot was used in the data analysis. Average air temperature in the 2 weeks before soil moisture measurements was $16.8^{\circ} \mathrm{C}$ and mean precipitation was $1.1 \mathrm{~mm}$, with the last rain occurring three (GE) and 4 days (AU) prior to sampling dates (Weather Underground 2014).

\section{Data analyses}

Statistical analyses were performed using the software $\mathrm{R}$ (R Development Core Team 2012, version 2.15.2). We examined the potential influence of the two irrigation techniques on the species-area relationship at two levels. At the plot level, we calculated the intercepts and slopes (both log-transformed) of each of the 36 species-area relationships. To test whether the two types of irrigation affected the intercepts and slopes of species-area relationships, nested analyses of variance (ANOVA) were used with the factor irrigation type nested in study area. To minimize local variation in environmental factors (exposition, inclination, soil type), we considered differences in the cumulative species curves between pairs consisting of a traditionally irrigated and its nearest situated sprinkler-irrigated meadow (hereafter meadow-pair level). For this purpose, we calculated mean species richness for each subplot size (ranging from 0.01 to $40.96 \mathrm{~m}^{2}$ ) for each meadow and determined the intercept and slope of the resulting species-area relationship of this meadow. Paired $t$ tests were applied to examine whether pairs of differently irrigated meadows $(n=6)$ differed in the intercepts and slopes of their species-area relationships.

We constructed two types of distance matrices to analyse differences in the spatial pattern of the soil characteristics between traditionally and sprinklerirrigated meadows. The first distance matrix 
considered the geographical coordinates of the 13 sampling points (midpoint of each subplot) to calculate Euclidean distances among all sampling points using the ecodist package (Goslee and Urban 2007). The pairwise distances among the 13 sampling points within a plot ranged from 10 to $570 \mathrm{~cm}(n=78)$ and were the same for all plots and for all soil characteristics investigated. The second distance matrix had exactly the same structure, but considered a particular soil characteristic instead of geographical coordinates. The distance matrices were calculated separately for all plots for the following characteristics: soil moisture, soil $\mathrm{pH}$, SOM, total soil organic nitrogen content $(\operatorname{OrgN})$, total phosphorus content (PT) and plant available phosphorus content (PP) resulting in a total of 12 distance matrices. Due to a missing value in the sprinkler-irrigated meadow GE2 only 11 distance matrices were obtained for PT. We performed Mantel tests with 999 permutations for each distance matrix of the soil characteristics and calculated Mantel correlograms using the mantel and mgram functions of the ecodist package (Goslee and Urban 2007). To examine whether the Mantel coefficients $\left(r_{\mathrm{M}}\right)$ of the soil characteristics differed between irrigation techniques, we created reference bands for equality derived from the standard errors of the difference between $r_{\mathrm{M}}$ at each lag distance (Bowman and Young 1996) using the sm.ancova function of the $s m$ package with a smoothing parameter $h=20$ (Bowman and Azzalini 2013). At scales at which the plotted means of $r_{M}$ exceeded this reference band, irrigation technique had a significant influence on the spatial pattern of the soil characteristic investigated (Bowman and Young 1996).

Finally, to assess the spatial scale of positive autocorrelation of soil characteristics, we determined the largest lag distance with a significant positive $r_{M}$ value for each soil characteristic and for each Mantel correlogram for both irrigation techniques separately. If there was no positive autocorrelation within a Mantel correlogram, we took 0 as lag distance. In the results section, we present the mean lag distance for each irrigation type and soil characteristic.

\section{Results}

A total of 149 vascular plant species were recorded in the two types of meadows, 122 species $(81.9 \%)$ in traditionally irrigated meadows and 133 species $(89.3 \%)$ in sprinkler-irrigated meadows. Considering single meadows, the cumulative number of species ranged from 57 to 82 species (mean \pm SE $68.8 \pm 4.0$ ) in traditionally irrigated meadows and from 63 to 78 species $(70.0 \pm 2.8)$ in sprinkler-irrigated meadows.

Species-area relationship

At the plot level $\left(40.96 \mathrm{~m}^{2}\right)$, plant species richness ranged from 39 to 70 species (mean \pm SE $53.1 \pm 2.1$ ) in traditionally irrigated meadows and from 47 to 64 species $(53.9 \pm 1.1)$ in sprinkler-irrigated meadows. The relationship between cumulative species richness and area was significant in all 36 plots (all $p<0.0001)$. However, in none of the species-area curves an asymptote was reached (Fig. 2). Neither the intercepts nor the slopes of the species-area curves were influenced by the type of irrigation (ANOVA, intercept: $F_{1,32}=0.019, p=0.89$; slope: $F_{1,32}=$ $0.17, p=0.68$ ). However, the interaction between study area and irrigation technique had a significant effect on the intercepts $\left(F_{2,32}=3.60, p=0.039\right)$, but not on the slopes of the species-area curves $\left(F_{2,32}=\right.$ $1.23, p=0.31)$. Intercepts were higher in the study area GE (mean $\pm \mathrm{SE} 3.34 \pm 0.04$ ) than in $\mathrm{AU}$ (3.23 \pm 0.03$)$.

At the meadow-pair level, neither the intercepts (paired $t$ test, $t=-0.01$, d.f. $=5, p=0.99$ ) nor the slopes $(t=-0.80$, d.f. $=5, p=0.46)$ of the mean species-area curves differed between meadows with either irrigation technique.

Spatial variation in soil characteristics

In general, the mean values of the Mantel coefficients $\left(r_{\mathrm{M}}\right)$ of the assessed soil characteristics decreased with increasing distance between the sampling points except for total soil organic matter content (SOM) and total soil organic nitrogen content (OrgN), which both increased with increasing distance in the sprinkler-irrigated meadows (Fig. 3).

The type of irrigation did not affect the spatial variation in soil moisture, $\operatorname{OrgN}$, total phosphorus content (PT) and plant available phosphorus content (PP) (non-parametric ANCOVA, test of equality, soil moisture: $p=0.93$; OrgN: $p=0.52$; PT: $p=0.90$; PP: $p=0.99$; Fig. 3a, d-f). In contrast, irrigation technique affected the spatial pattern of soil $\mathrm{pH}$ and 

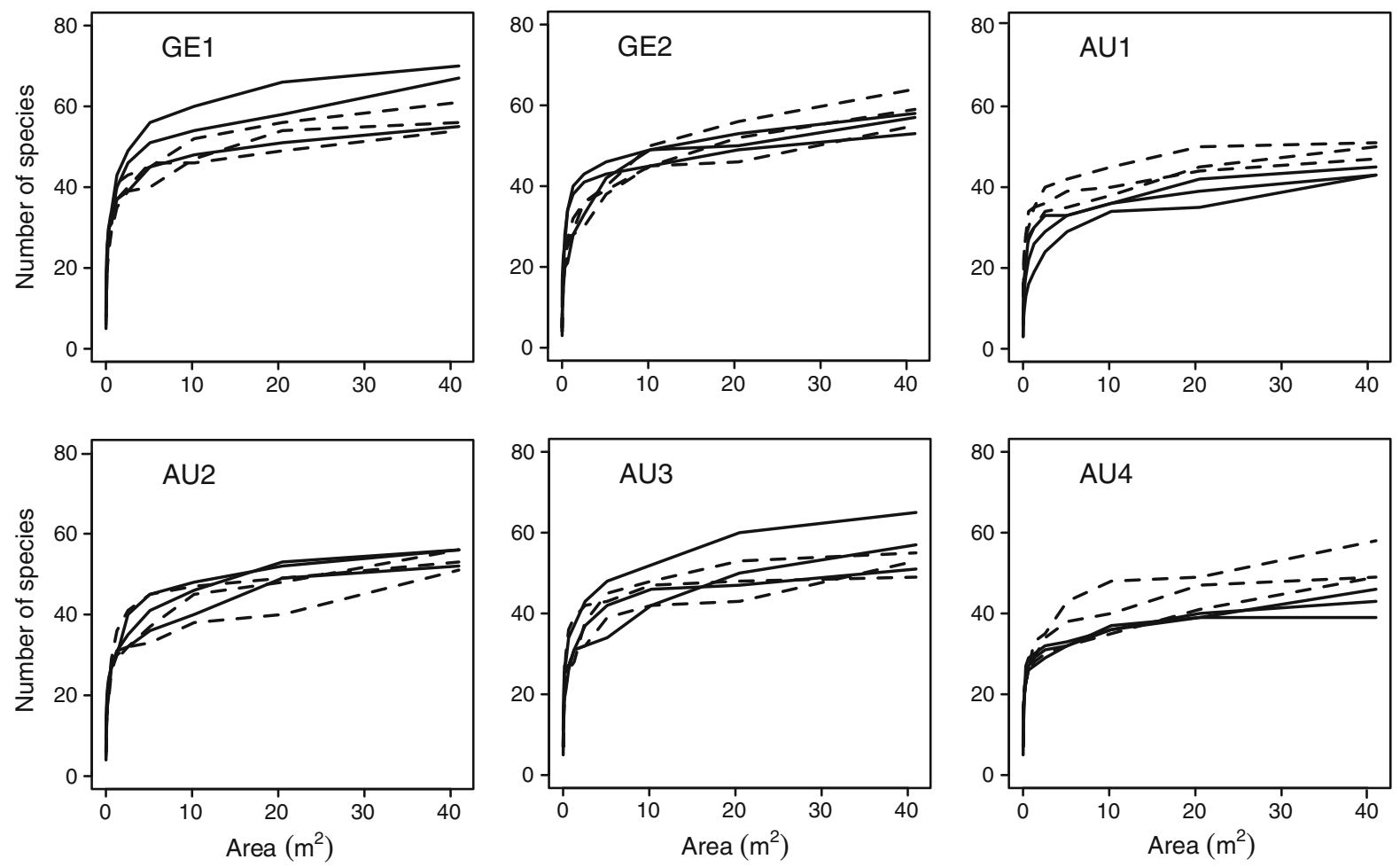

Fig. 2 Species-area curves of six pairs of traditionally and sprinkler-irrigated meadows, two in Guttet-Erschmatt (GE) and four in Ausserberg (AU). In each meadow pair, three plots were

SOM (pH: $p=0.011$; SOM: $p=0.019$; Fig. 3b, c). For both soil characteristics the means of $r_{\mathrm{M}}$ exceeded the reference band at sampling distances between 440 and $520 \mathrm{~cm}$. However, none of the means within this range showed a positive autocorrelation (Fig. 3b, c). In contrast, the mean $r_{\mathrm{M}}$ values of $\mathrm{pH}$ between 40 and $120 \mathrm{~cm}$ were significantly positively autocorrelated in the sprinkler-irrigated meadows, whereas no similar autocorrelation was found in the traditionally irrigated meadows (Fig. 3b).

The pattern of autocorrelation of soil characteristics did not differ between the two irrigation techniques. In most soil characteristics, no positive spatial autocorrelation among samples was found. Only in a few cases, average spatial autocorrelation ranged from a few to $60 \mathrm{~cm}$ (Appendix; Fig. S2).

\section{Discussion}

The present study showed that traditionally and sprinkler-irrigated hay meadows did not differ in the examined in a traditionally irrigated meadow (dashed lines) and three in a sprinkler-irrigated meadow (solid lines)

shape of the plant species-area relationships and in the small-scale patterns of soil characteristics (exceptions being the spatial distribution of soil $\mathrm{pH}$ and $\mathrm{SOM}$ ).

Plant species richness of hay meadows

Based on a total plot area of $122.88 \mathrm{~m}^{2}$, we recorded on average 69.4 plant species per meadow. In a previous study conducted in the same region (eight of the 16 meadows were also considered in the present study), an average of 54 species was found per meadow in a single plot of $100 \mathrm{~m}^{2}$ (Riedener et al. 2013). This difference can be explained by a smaller sampling area, different arrangements of sampling plots (one $10 \times 10 \mathrm{~m}$ plot versus three $6.4 \times 6.4 \mathrm{~m}$ plots randomly distributed across a meadow), and the slightly but not significantly lower plant diversity in meadows located in Birgisch-Mund not considered in the present study.

Plant species richness recorded in the plots of the present study (39-70 species per $40.96 \mathrm{~m}^{2}$ ) was relatively high compared to plots in other Trisetetum- 

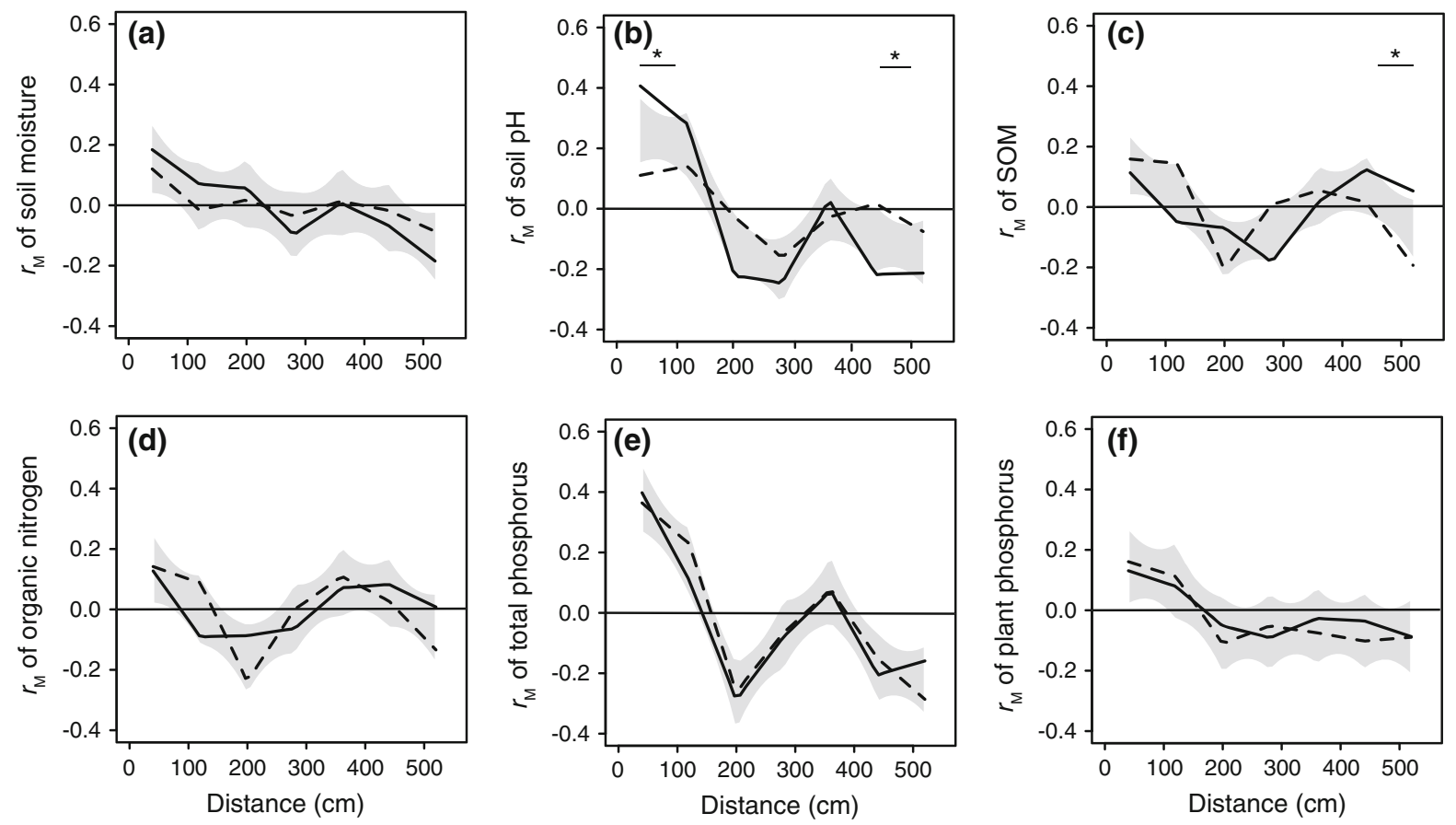

Fig. 3 Non-parametric curves for the mean Mantel coefficients $\left(r_{\mathrm{M}}\right)$ of the six soil characteristics in traditionally (dashed lines) and sprinkler-irrigated (solid lines) meadows. Reference bands for equality of $r_{\mathrm{M}}$ in the two differently irrigated meadows are

meadows situated on similar elevations in the Swiss Alps (31-34 species per $100 \mathrm{~m}^{2}$, Homburger and Hofer 2012 and 23-43 species per $25 \mathrm{~m}^{2}$, Volkart and Godat 2007). However, none of the species-area curves reached the asymptote within the range of the plot sizes examined in the present study. This was also true when the data from the three plots of a meadow were combined (total area: $122.88 \mathrm{~m}^{2}$; data not shown). This indicates a high plant diversity, as well as a pronounced variation in the spatial distribution of single plant species within a meadow compared to vegetation surveys in other Trisetetum meadows (Marschall 1947; Ellenberg 1986; Lüth et al. 2011). The pronounced variation in the spatial distribution of single plant species can be explained by various factors including clonal reproduction, uneven distribution of soil nutrients, variation in soil depth and seed distribution.

Effect of irrigation technique on species-area curves

We assumed that traditionally irrigated meadows have an uneven distribution of water, which results in a presented. At distances where the means of $r_{\mathrm{M}}$ exceeded the reference band, the two curves differ significantly from each other, as indicated by the asterisk. Smoothing parameter $h=20$. SOM soil organic matter content

higher variation in the spatial distribution of plant species than in sprinkler-irrigated meadows. As a consequence, the slopes of the species-area relationships should differ between meadows irrigated by different techniques. However, this was not the case in our study. A possible explanation for the discrepancy is that the water distribution of sprinklers is more heterogeneous than commonly assumed (Meurer and Müller 1987). In fact, sprinkler irrigation systems in the study areas obtain their water from channels, and hence only rely on natural water pressure gradients from the sloping land (Crook 1997). Seasonal variation in water supply can, therefore, influence the reach of a sprinkler and thus the distribution of water. Furthermore, spray water can be misdirected by wind (Meurer and Müller 1987) and additional water can be supplied by uphill-situated meadows irrigated in the traditional way (R. L. M., pers. obs.). Moreover, the spatial arrangement of sprinklers at permanent positions and the seasonal relocation of mobile sprinklers may lead to a mosaic of partly overlapping circular areas with increased water supply and gaps that are tenuously irrigated. Hence, as practiced in our study 
areas, the distribution of water by sprinklers might be as heterogeneous as in the traditional irrigation technique. As a consequence, the two differently irrigated meadow types show a similar spatial distribution of plant species.

However, differences in the intercept of the species-area relationship were recorded between the two study areas. Irrespective of plot size, plant diversity was higher in Guttet-Erschmatt (GE) than in Ausserberg (AU; Fig. 2). This might be a result of site-specific differences in elevation (Kreft et al. 2008), different grazing animals (GE: horses and occasionally cattle, AU: cattle and sheep), amount of fertilizer, or meadow size (Gaujour et al. 2012).

Effect of irrigation technique on the spatial pattern of soil characteristics

Mantel correlograms revealed that traditionally and sprinkler-irrigated meadows did not differ in the spatial patterns of the soil characteristics examined, except in soil $\mathrm{pH}$ (see below). This result is in agreement with the findings of the plant species-area relationship.

Mantel correlograms also provide insight into the occurrence and spatial scale of autocorrelations (Borcard and Legendre 2012). In general, $r_{\mathrm{M}}$ decreased with increasing distances between sampling points, indicating a decreasing dependency the longer the distances between the sampling points were. Average positive autocorrelations were only found over distances ranging from 7 to $60 \mathrm{~cm}$ (Appendix). This suggests a high heterogeneity in soil characteristics even at a very small spatial scale. Thus, the heterogeneity in soil nutrients and soil moisture observed in this study could have led to the spatial heterogeneity in plant species and the high plant species richness, thereby supporting the view that heterogeneity in soil characteristics is positively linked to plant species richness (Harner and Harper 1976; Davies et al. 2005; Zhou et al. 2008).

For soil $\mathrm{pH}$, a positive autocorrelation was recorded in sprinkler-irrigated meadows over a distance of 40-120 cm (Appendix). In contrast, no autocorrelation was found in traditionally irrigated meadows. As suggested by Meurer and Müller (1987), these differences might be explained by differences in the sediment content of the water used for irrigation. In sprinkler irrigation, melt water passes a settlement tank prior to entering the tubes, which substantially reduces sediments and organic materials and thus prevents the clogging of nozzles. In the traditional irrigation technique, unfiltered melt water is used. Through this sediment input irrigation additionally contributes to soil development (Meurer and Müller 1987). These differences in the sediment input and differences in the spatial distribution of water could have affected the pattern observed for soil $\mathrm{pH}$. In contrast, small-scale differences in soil characteristics were hardly influenced by differences in the bedrock type, because in the present study, soil characteristics including soil $\mathrm{pH}$ were measured in the upper most $5 \mathrm{~cm}$ of the soil layer.

Irrigation technique affected the spatial pattern of soil $\mathrm{pH}$ and SOM at sampling distances of 400 and $520 \mathrm{~cm}$. However, in both cases, $r_{M}$ values were not significantly different from zero indicating that there was no autocorrelation at this distance.

\section{Conclusion}

The present study demonstrated a pronounced smallscale heterogeneity in the spatial distribution of both plants and soil characteristics in the hay meadows investigated. However, this variation was not influenced by the irrigation technique used. As it is applied on the slopes of these study areas, sprinkler irrigation does not appear to alter the spatial pattern of plant diversity compared with the traditional irrigation technique. Furthermore, our study areas are characterised by a patchy landscape consisting of small meadows, pastures, fallow land, hedgerows, few buildings and roads with adjacent forest. Therefore, the lack of any influence of irrigation technique on the spatial pattern of plant diversity and soil characteristics should not be extrapolated to large, homogeneous grassland areas that are more intensively irrigated.

Acknowledgments Special thanks go to the farmers and landowners for permitting field surveys on their land, to $\mathrm{K}$. Liechti and R. Rodewald for preparatory work and to A. Baur and two anonymous reviewers for their valuable comments on the manuscript. Financial support was received from the National Research Programme NRP 61 (Sustainable Water Management). 


\section{Appendix}

See Appendix Table 1.

Table 1 Positive spatial autocorrelation obtained from individual Mantel correlograms for the six soil characteristics in (a) traditionally and (b) sprinkler-irrigated meadows

\begin{tabular}{llllll}
\hline Plot & Soil moisture & Soil $\mathrm{pH}$ & SOM & Nitrogen & Total phosphorus
\end{tabular}

(a) Traditional irrigation

\begin{tabular}{|c|c|c|c|c|c|c|}
\hline GE1 & 0.00 & 0.00 & 0.00 & 0.00 & 119.99 & 0.00 \\
\hline GE2 & 0.00 & 0.00 & 0.00 & 0.00 & 40.00 & 40.00 \\
\hline AU1 & 40.00 & 0.00 & 0.00 & 40.00 & 40.00 & 0.00 \\
\hline AU2 & 0.00 & 0.00 & 0.00 & 0.00 & 0.00 & 119.99 \\
\hline AU3 & 0.00 & 0.00 & 0.00 & 119.99 & 119.99 & 0.00 \\
\hline AU4 & 0.00 & 0.00 & 0.00 & 0.00 & 40.00 & 0.00 \\
\hline Mean & 6.67 & 0.00 & 0.00 & 26.67 & 60.00 & 26.67 \\
\hline Median & 0.00 & 0.00 & 0.00 & 0.00 & 40.00 & 0.00 \\
\hline \multicolumn{7}{|c|}{ b) Sprinkler irrigation } \\
\hline GE1 & 0.00 & 119.99 & 0.00 & 0.00 & 40.00 & 0.00 \\
\hline GE2 & 40.00 & 119.99 & 0.00 & 0.00 & NA & 0.00 \\
\hline AU1 & 0.00 & 40.00 & 0.00 & 0.00 & 40.00 & 0.00 \\
\hline AU2 & 0.00 & 40.00 & 0.00 & 0.00 & 0.00 & 0.00 \\
\hline AU3 & 0.00 & 0.00 & 0.00 & 0.00 & 119.99 & 0.00 \\
\hline AU4 & 0.00 & 40.00 & 0.00 & 40.00 & 40.00 & 0.00 \\
\hline Mean & 6.67 & 60.00 & 0.00 & 6.67 & 48.00 & 0.00 \\
\hline Median & 0.00 & 40.00 & 0.00 & 0.00 & 40.00 & 0.00 \\
\hline
\end{tabular}

The table shows the maximal distance $(\mathrm{cm})$ for positive autocorrelation among the samples of a given soil characteristic within a plot, as well as mean and median for each soil characteristic. No positive autocorrelation indicates a high variability among samples

SOM soil organic matter content

\section{References}

Allen SE (1989) Chemical analysis of ecological materials, 2nd edn. Blackwell Scientific, Oxford

Baur B, Ewald KC, Freyer B, Erhardt A (1997) Ökologischer Ausgleich und Biodiversität. Birkäuser Verlag, Basel

Baur B, Duelli P, Edwards PJ, Jenny M, Klaus G, Künzle I, Martinez S, Pauli D, Peter K, Schmid B, Seidl I, Suter W (2004) Biodiversität in der Schweiz-Zustand, Erhaltung, Perspektiven. Haupt Verlag, Bern

Baur B, Cremene C, Groza G, Rakosy L, Schileyko AA, Baur A, Stoll P, Erhardt A (2006) Effects of abandonment of subalpine hay meadows on plant and invertebrate diversity in Transylvania, Romania. Biol Conserv 132:261-273

Borcard D, Legendre P (2012) Is the Mantel correlogram powerful enough to be useful in ecological analysis? A simulation study. Ecology 93:1473-1481

Bowman A, Azzalini A (2013) R package 'sm': nonparametric smoothing methods (version 2.2-5). http://www.stats.gla. ac.uk/ adrian/sm. Accessed Nov 2013
Bowman A, Young S (1996) Graphical comparison of nonparametric curves. J R Stat Soc 45:83-98

Braschler B, Zschokke S, Dolt C, Thommen GH, Oggier P, Baur B (2004) Grain-dependent relationships between plant productivity and invertebrate species richness and biomass in calcareous grasslands. Basic Appl Ecol 5:15-24

Bremner JM (1965) Total nitrogen. In: Black CA (ed) Methods of soil analysis, Part 2. American Society of Agronomy, Madison, pp 1149-1178

Condit R, Hubbell SP, Lafrankie JV, Sukumar R, Manokaran N, Foster RB, Ashton PS (1996) Species-area and speciesindividual relationships for tropical trees: a comparison of three 50-ha plots. J Ecol 84:549-562

Connor EF, McCoy ED (1979) The statistics and biology of the species-area relationship. Am Nat 113:791-833

Crook DS (1997) Sustainable mountain irrigation? The bisses of the Valais, Switzerland: a holistic appraisal. Dissertation, University of Huddersfield

Crook DS, Jones AM (1999) Design principles from traditional mountain irrigation systems (bisses) in the Valais, Switzerland. Mt Res Dev 19:79-99 
Davies KF, Chesson P, Harrison S, Inouye BD, Melbourne BA, Rice KJ (2005) Spatial heterogeneity explains the scale dependence of the native-exotic diversity relationship. Ecology 86:1602-1610

Diacon-Bolli J, Dalang T, Holderegger R, Bürgi M (2012) Heterogeneity fosters biodiversity: linking history and ecology of dry calcareous grasslands. Basic Appl Ecol 13:641-653

Ellenberg H (1986) Vegetation Mitteleuropas mit den Alpen in ökologischer Sicht, 4th edn. Eugen Ulmer, Stuttgart

Gaujour E, Amiaud B, Mignolet C, Plantureux S (2012) Factors and processes affecting plant biodiversity in permanent grasslands. A review. Agron Sustain Dev 32:133-160

Giladi I, Ziv Y, May F, Jeltsch F (2011) Scale-dependent determinants of plant species richness in a semi-arid fragmented agro-ecosystem. J Veg Sci 22:983-996

Goslee SC, Urban DL (2007) The ecodist package for dissimilarity-based analysis of ecological data. J Stat Softw 22:1-19

Harner RF, Harper KT (1976) The role of area, heterogeneity, and favorability in plant species diversity of Pinyon-Juniper ecosystems. Ecology 57:1254-1263

Harte J, McCarthy S, Taylor K, Kinzig A, Fischer ML (1999) Estimating species-area relationships from plot to landscape scale using species spatial-turnover data. Oikos 86:45-54

He FL, Legendre P (2002) Species diversity patterns derived from species-area models. Ecology 83:1185-1198

Homburger H, Hofer G (2012) Diversity change of mountain hay meadows in the Swiss Alps. Basic Appl Ecol 13:132-138

Hortal J, Borges PAV, Gaspar C (2006) Evaluating the performance of species richness estimators: sensitivity to sample grain size. J Anim Ecol 75:274-287

Kallimanis AS, Mazaris AD, Tzanopoulos J, Halley JM, Pantis JD, Sgardelis SP (2008) How does habitat diversity affect the species-area relationship? Global Ecol Biogeogr 17:532-538

Kolasa J, Manne LL, Pandit SN (2012) Species-area relationships arise from interaction of habitat heterogeneity and species pool. Hydrobiologia 685:135-144

Kreft H, Jetz W, Mutke J, Kier G, Barthlott W (2008) Global diversity of island floras from a macroecological perspective. Ecol Lett 11:116-127

Leibundgut C (2004) Historical meadow irrigation in Europe-a basis for agricultural development. In: The basis of civilization-water science? Proceedings of the UNESCO/IAHS/ IWHA symposium, vol 286. IAHS Publication, pp 77-87

Lüth C, Tasser E, Niedrist G, Via JD, Tappeiner U (2011) Plant communities of mountain grasslands in a broad crosssection of the Eastern Alps. Flora 206:433-443

Marschall F (1947) Die Goldhaferwiese (Trisetetum flavescentis) der Schweiz-Eine soziologisch-ökologische Studie. Dissertation, ETH Zurich

MeteoSwiss (2013) Climate normals Visp, reference period 1981-2010. Federal Office of Meteorology and Climatology MeteoSwiss. http://www.meteoschweiz.admin.ch/web/de/ klima/klima_schweiz/klimadiagramme.html. Accessed Nov 2013

Meurer M, Müller HN (1987) Ökologische Auswirkungen und Schutzwürdigkeit der traditionellen Wiesenbewässerung im Simplon-Gebiet (Wallis). Verh GfÖ 15:91-104
Nilsson IN, Nilsson SG (1985) Experimental estimates of census efficiency and pseudoturnover on islands: error trend and between-observer variation when recording vascular plants. J Ecol 73:65-70

Olofsson J, de Mazancourt C, Crawley MJ (2008) Spatial heterogeneity and plant species richness at different spatial scales under rabbit grazing. Oecologia 156:825-834

Poschlod P, WallisDeVries MF (2002) The historical and socioeconomic perspective of calcareous grasslands-lessons from the distant and recent past. Biol Conserv 104:361-376

Preston FW (1960) Time and space and the variation of species. Ecology 41:611-627

Proença V, Pereira HM (2013) Species-area models to assess biodiversity change in multi-habitat landscapes: the importance of species habitat affinity. Basic Appl Ecol 14:102-114

R Development Core Team (2012) R: a language and environment for statistical computing. R Foundation for Statistical Computing, Vienna. http://www.Rproject.org

Riedener E, Rusterholz H-P, Baur B (2013) Effects of different irrigation systems on the biodiversity of species-rich hay meadows. Agric Ecosyst Environ 164:62-69

Riedener E, Rusterholz H-P, Baur B (2014) Land-use abandonment owing to irrigation cessation affects the biodiversity of hay meadows in an arid mountain region. Agric Ecosyst Environ 185:144-152

Rosenzweig ML (1995) Species diversity in space and time. Cambridge University Press, New York

Shen G, Yu M, Hu X-S, Mi X, Ren H, Sun I-F, Ma K (2009) Species-area relationships explained by the joint effects of dispersal limitation and habitat heterogeneity. Ecology 90:3033-3041

Shi J, Ma K, Wang J, Zhao J, He K (2010) Vascular plant species richness on wetland remnants is determined by both area and habitat heterogeneity. Biodivers Conserv 19:1279-1295

Shmida A, Wilson MV (1985) Biological determinants of species diversity. J Biogeogr 12:1-20

Strijker D (2005) Marginal lands in Europe-causes of decline. Basic Appl Ecol 6:99-106

Tasser E, Tappeiner U (2002) Impact of land use changes on mountain vegetation. Appl Veg Sci 5:173-184

Tilman D (1982) Resource competition and community structure. Monographs in population biology No. 17. Princeton University Press, Princeton

Volkart G, Godat S (2007) Effets de l'arrosage sur la végétation de l'herbage 1988-2006: Analyse de la végétation après réintroduction de l'arrosage il y a 18 ans à Martisberg, Haut-Valais. Atena, Fribourg

Weather Underground (2014) Weather history for Sion, Valais. http://wunderground.com. Accessed May 2014

Weiher E, Howe A (2003) Scale-dependence of environmental effects on species richness in oak savannas. J Veg Sci 14:917-920

Werner P (1995) Les bisses et leur environnement naturel en Valais: utilité des observations de la végétation actuelle pour les reconstitutions historiques. Ann Valais 70:75-90

White EP (2004) Two-phase species-time relationships in North American land birds. Ecol Lett 7:329-336

Zhou Z, Sun OJ, Luo Z, Jin H, Chen Q, Han X (2008) Variation in small-scale spatial heterogeneity of soil properties and vegetation with different land use in semiarid grassland ecosystem. Plant Soil 310:103-112 